\title{
Effect of Seed Rates and Varieties on Yield of Rice Fallow Mustard and their Economics
}

\author{
B. Rajyalakshmi ${ }^{{ }^{*}}$, B. Venkateswarlu and P.V.N. Prasad \\ Department of Agronomy, Agricultural College, Bapatla, Acharya N.G. Ranga Agricultural \\ University, India \\ *Corresponding author
}

\section{Keywords}

Mustard, Seed rates, Varieties

Article Info

Accepted:

20 January 2019

Available Online:

10 February 2019

\section{A B S T R A C T}

A field experiment was conducted during rabi, 2017-2018 on clay soils of Agricultural College Farm, Bapatla to find out the effect of seed rates and varieties on yield of rice fallow mustard and to calculate economics. The treatments consisted of four seed rates $\left(\mathrm{S}_{1}: 6 \mathrm{~kg} \mathrm{ha}^{-1}, \mathrm{~S}_{2}: 8 \mathrm{~kg} \mathrm{ha}^{-1}, \mathrm{~S}_{3}: 10 \mathrm{~kg} \mathrm{ha}^{-1}\right.$ and $\left.\mathrm{S}_{4}: 12 \mathrm{kgha}^{-1}\right)$ and three varieties $\left(\mathrm{V}_{1}: \mathrm{NPJ}-112\right.$, $\mathrm{V}_{2}$ : PM-28, $\mathrm{V}_{3}$ : Pusa bold) and laid out in factorial randomized block design and replicated thrice. Experimental results revealed that significantly highest seed yield $\left(650 \mathrm{~kg} \mathrm{ha}^{-1}\right)$ and stalk yield $\left(1450 \mathrm{~kg} \mathrm{ha}^{-1}\right)$ was recorded in seed rate $12 \mathrm{~kg} \mathrm{ha}^{-1}$. Among varieties PM-28 significantly recorded highest seed yield $\left(665 \mathrm{~kg} \mathrm{ha}^{-1}\right)$ and stalk yield $\left(1652 \mathrm{~kg} \mathrm{ha}^{-1}\right)$. Significantly highest harvest index (41.5\%) was recorded with the variety NPJ-112 and harvest index was non-significant for seed rates. The interaction between seed rates and varieties was found not significant for seed yield, straw yield and harvest index of mustard. The highest gross return (Rs 29, $268 \mathrm{ha}^{-1}$ ), net return (Rs 17, $308 \mathrm{ha}^{-1}$ ) and return per rupee invested (Rs 1.45) was recorded with the $12 \mathrm{~kg}$ seed $\mathrm{ha}^{-1}$. The variety PM-28 recorded highest gross return (Rs 29, $\left.961 \mathrm{ha}^{-1}\right)$, net return (Rs 18, $241 \mathrm{ha}^{-1}$ ) and return per rupee invested (Rs 1.56).

\section{Introduction}

Mustard (Brassica juncea L.) is the third important oilseed crop in the world after soybean and oil palm. Among the seven edible oilseeds cultivated in India, rapeseedmustard contributes $28.6 \%$ in the total production of oilseeds. India's average production of rapeseed and mustard was 6.2 million tonnes in an area of 5.7 million ha with an average productivity of $10.83 \mathrm{~kg} \mathrm{ha}^{-1}$ in 2014-15. In AP, the acerage and production of mustard is 0.6 Lakh hectares area and 0.3
Lakh tonnes respectively with productivity of $500 \quad \mathrm{~kg} \quad \mathrm{ha}^{-1}$ in 2014-15 (http://www.indiastat.com).

The crop can be raised well both under irrigated and rainfed conditions, and also on residual fertility and residual soil moisture conditions, in rice fallows. Effective management of natural resources, integrated approach to plant water, nutrient and pest management and extension of Rapeseedmustard cultivation to newer areas under different cropping systems will play a key 
role in further increasing and stabilizing the productivity and production of rapeseedmustard. Optimum seed rate play an important role to fully exploit the genetic potential of variety as it provides optimum growth conditions such as temperature, light, humidity, and rainfall etc. A process of yield formation is highly variable and depends on genetic, environmental and agronomic factors as well as interaction between them BebiGogoi (2017). Hence, using improved varieties at optimum seed rate is one aspect in mustard in order to achieve higher yields. In light of these, the present investigation was therefore undertaken to study the effect of seed rates and varieties on yield of rice fallow mustard and to calculate economics.

\section{Materials and Methods}

Afield experiment was carried out on clay soil of Agricultural College Farm, Bapatla during rabi, 2017-18. The soil was saline in reaction and low in organic carbon $(0.02 \%)$, low in available nitrogen $\left(226.77 \mathrm{~kg} \mathrm{ha}^{-1}\right)$, medium in available phosphorus $\left(31.95 \mathrm{~kg} \mathrm{ha}^{-1}\right)$, high in available potassium (556.45 kg ha $\mathrm{kg}^{-1}$ ) and available sulphur $\left(23.25 \mathrm{~kg} \mathrm{ha}{ }^{-1}\right)$. The experiment was laid out in factorial randomized block design and replicated thrice. The treatment comprised of four seed rates $\left(S_{1}: 6 \mathrm{~kg} \mathrm{ha}^{-1}, S_{2}: 8 \mathrm{~kg} \mathrm{ha}^{-1}, S_{3}: 10 \mathrm{~kg} \mathrm{ha}^{-1}\right.$, $\mathrm{S}_{4}: 12 \mathrm{~kg} \mathrm{ha}^{-1}$ ) allotted to factor-A and three varieties $\left(\mathrm{V}_{1}\right.$ : NPJ-112, $\mathrm{V}_{2}$ : PM-28, V 3 : Pusa bold) allotted to factor-B. Mustard was sown on $1^{\text {st }}$ December 2017.Mustard was broadcasted before four days of harvesting of rice. The experiment was sown on 01-122018 and harvested on 23-02-2018. During the crop growth season climate was nearer to normal. The weekly mean maximum temperatures ranged from $29.94^{\circ} \mathrm{C}$ to $35.02^{\circ} \mathrm{Cand}$ the weekly mean minimum temperatures ranged from $16.01{ }^{\circ} \mathrm{C}$ to $19.31^{\circ} \mathrm{C}$, respectively with average maximum temperatures of $30.89^{\circ} \mathrm{C}$ and minimum temperatures of $17.82^{\circ} \mathrm{C}$, respectively. The weekly mean relative humidity ranged from 60.80 to 74.65 per cent with an average of 71.33 per cent. No rainfall was received during the entire crop growth period. Overall, the climatic conditions were normal and suitable for the successful cultivation of mustard crop with little incidence of pests which were controlled by suitable insecticidal sprays and there was no disease incidence.

\section{Results and Discussion}

\section{Seed yield}

The seed yield of rice fallow mustard (Table 1) varied significantly due to different seed rates $\left(\mathrm{kg} \mathrm{ha}^{-1}\right)$. The highest seed yield $(650 \mathrm{~kg}$ $\mathrm{ha}^{-1}$ ) was recorded with12 $\mathrm{kg}$ seed $\mathrm{ha}^{-1}$ and was statistically comparable with the seed yield of $601 \mathrm{~kg} \mathrm{ha}^{-1}$ registered by $10 \mathrm{~kg}$ seed $\mathrm{ha}^{-1}$ only. The seed yield recorded 601,577 and $565 \mathrm{~kg} \mathrm{ha}^{-1}$ in $10 \mathrm{~kg} \mathrm{ha}^{-1}, 8 \mathrm{~kg} \mathrm{ha}^{-1}$ and 6 $\mathrm{kg} \mathrm{ha}{ }^{-1}$, seed rates, respectively were statistically comparable with one another. This might be due to higher nutrient uptake, greater vegetative growth, elevated yield attributes, higher dry matter partitioning towards economic part and better light interception. Yield variability among mustard cultivars also attributed to genetic characters and environmental effects Khajuria et al (2017). High planting densities promote the development of vegetative organs before anthesis and effective nutrition uptake dynamics to the reproductive organs after anthesis, which strongly increased seed yield Ma et al (2014).

Seed yield of rice fallow mustard was also significantly influenced by the varieties under test. The highest seed yield of $665 \mathrm{~kg} \mathrm{ha}^{-1}$ was registered by PM-28 variety which was significantly superior to Pusa bold $(511 \mathrm{~kg}$ $\mathrm{ha}^{-1}$ ) only and statistically comparable to NPJ112 with $618 \mathrm{~kg}$ seed yield per hectare. 
Production of higher yield by different varieties might be due to the contribution of cummulative favorable effects of the crop characteristics viz., number of branches per plant, siliquae per plant and seeds per siliquae Meena et al (2013).

\section{Stalk yield}

Data pertaining to stalk yield for rice fallow mustard are presented in (Table 1) and the data reveals that significantly the highest stalk yield was registered in the treatment receiving $12 \mathrm{~kg}$ seed $\mathrm{ha}^{-1}\left(1450 \mathrm{~kg} \mathrm{ha}^{-1}\right)$ and was significantly superior to the lowest seed rate i.e. $6 \mathrm{~kg} \mathrm{ha}^{-1}$ recorded $1300 \mathrm{~kg} \mathrm{ha}^{-1}$ stalk yield alone. $12 \mathrm{~kg}$ seed rate $\mathrm{ha}^{-1}$ was statistically comparable with $10 \mathrm{~kg}$ seed $\mathrm{ha}^{-1}(1395 \mathrm{~kg}$ $\mathrm{ha}^{-1}$ ) and $8 \mathrm{~kg}$ seed rate ha ${ }^{-1}$ (1346 kg ha $\left.{ }^{-1}\right)$. The highest stalk yield was observed at higher planting density whereas, the lowest was observed at lower planting density. The decrease in stalk yield from higher to lower planting density is mainly attributed to the higher plant population unit area ${ }^{-1} \mathrm{Neha}$ et al(2014).Higher plant population at higher seed rates, taller plants, more dry matter per unit area at higher plant populations might be the reason for the higher stalk yield at higher populations. Similar findings were also reported by Thakuria and Thakuria (2014).

There was a significant influence of varieties on the stalk yield of rice fallow mustard. The highest stalk yield was registered by PM-28 $\left(1652 \mathrm{~kg} \mathrm{ha}^{-1}\right)$ and it was followed by NPJ$112\left(1287 \mathrm{~kg} \mathrm{ha}^{-1}\right)$. The lowest stalk yield was registered by Pusa bold with $1179 \mathrm{~kg} \mathrm{ha}^{-1}$. This might be due to the plant height, dry matter accumulation and number of branches per plant was higher in PM-28 variety and was followed by NPJ-112 variety. Such varietal variation due to varieties was also ascribed by other scientists such as Khajuria et al., (2017).

\section{Harvest index}

Data pertaining to harvest index of rice fallow mustard are presented in Table 1 and the data reveals that varieties alone significantly influenced the harvest index and seed rate interaction with varieties was also not significant.

Harvest index was not significantly influenced due to different seed rates. The reason for the non-significant difference might be the non-dependence of this character due to fact this is more genetically influenced.

Varieties differed significantly among themselves in this regard. Highest harvest index $(41.5 \%)$ was recorded with the variety NPJ-112, which was on par with PM-28 $(33.1 \%)$ and Pusa bold (32.4\%). This character is the important yield attributes in the oil producing plants. Slight variations in harvest index, makes the greater dependence of this character, to the genetic structure of the plant. The balance between vegetative organs and reproductive reason for the slight variation in harvest index. Kumar et al (2017) also reported similar results.

\section{Economics}

The data on economics of rice fallow mustard as influenced by various seed rates and varieties are presented in Table 2. Significantly, the highest gross return (Rs29, $268 \mathrm{ha}^{-1}$ ) was recorded in the treatment receiving $12 \mathrm{~kg}$ seed $\mathrm{ha}^{-1}$ and was statistically comparable with the gross return of Rs 27 , 036 registered by the treatment received $10 \mathrm{~kg}$ $\mathrm{ha}^{-1}$ only. The gross return recorded Rs 27 , $036 \mathrm{ha}^{-1}$, Rs 25, $990 \mathrm{ha}^{-1}$ and Rs 25, $445 \mathrm{ha}^{-1}$ in $10 \mathrm{~kg} \mathrm{ha}^{-1}, 8 \mathrm{~kg} \mathrm{ha}^{-1}$ and $6 \mathrm{~kg} \mathrm{ha}^{-1}$, seed rate treatments, respectively were statistically comparable with one another. Seed yield at high seed rates was also higher. Hence these higher seed yields might have contributed for 
higher gross return. The current results are in conformity with the findings of Sharma (2013).

Significantly, the highest net return (Rs 17, $308 \mathrm{ha}^{-1}$ ) was recorded in the treatment receiving $12 \mathrm{~kg}$ seed $\mathrm{ha}^{-1}$ and was statistically comparable with the net return of Rs 15, 236 $\mathrm{ha}^{-1}$ registered by the treatment received $10 \mathrm{~kg}$ $\mathrm{ha}^{-1}$ only. The net return recorded Rs 15, 236 $\mathrm{ha}^{-1}$, Rs 14, $350 \mathrm{ha}^{-1}$ and Rs 13, $966 \mathrm{ha}^{-1}$ in 10 $\mathrm{kg} \mathrm{ha}^{-1}, 8 \mathrm{~kg} \mathrm{ha}^{-1}$ and $6 \mathrm{~kg} \mathrm{ha}^{-1}$, seed rate treatments, respectively were statistically comparable with one another. Lower seed yields at lower seed rates fetched lower gross return and net return. Similar findings were reported by Sharma (2013). Significantly, the highest return per rupee invested (Rs 1.45) was recorded in the treatment receiving $12 \mathrm{~kg}$ seed $\mathrm{ha}^{-1}$ and was statistically comparable with Rs 1.29 registered by the treatment received $10 \mathrm{~kg} \mathrm{ha}^{-1}$ only. Return per rupee invested recorded Rs 1.29, Rs 1.23 and Rs 1.29 in $10 \mathrm{~kg} \mathrm{ha}^{-1}, 8 \mathrm{~kg} \mathrm{ha}^{-1}$ and $6 \mathrm{~kg} \mathrm{ha}^{-1}$, seed rate treatments, respectively were statistically comparable with one another. This might be because of lesser grain yield and stover yield at the lowest seed rates of rice fallow-mustard. The results are in agreement with the findings of Meena et al., (2017).

Table.1 Seed yield $\left(\mathrm{kg} \mathrm{ha}^{-1}\right)$, Stalk yield $\left(\mathrm{kg} \mathrm{ha}^{-1}\right)$ and Harvest Index $(\%)$ of rice fallow mustard as influenced by seed rates and varieties

\begin{tabular}{|c|c|c|c|}
\hline Treatment & Seed yield & Stalk yield & Harvest Index \\
\hline \multicolumn{4}{|c|}{ Seed rates $\left(\mathrm{kg} \mathrm{ha}^{-1}\right)$} \\
\hline$S_{1}-6$ & 565 & 1300 & 35.7 \\
\hline$S_{2}-8$ & 577 & 1346 & 35.8 \\
\hline$S_{3}-10$ & 601 & 1395 & 35.5 \\
\hline$S_{4-12}$ & 650 & 1450 & 35.8 \\
\hline S.Em \pm & 20.18 & 36.31 & 1.98 \\
\hline $\mathrm{CD}(\mathrm{p}=\mathbf{0 . 0 5})$ & 59 & 106 & NS \\
\hline \multicolumn{4}{|l|}{ Varieties } \\
\hline NPJ-112 & 618 & 1287 & 41.5 \\
\hline PM-28 & 665 & 1652 & 33.1 \\
\hline Pusa bold & 511 & 1179 & 32.4 \\
\hline S.Em \pm & 17.47 & 31.44 & 1.72 \\
\hline $\mathrm{CD}(\mathrm{p}=0.05)$ & 51 & 92 & 5.0 \\
\hline \multicolumn{4}{|l|}{ Interaction (S X V) } \\
\hline S.Em \pm & 34.95 & 62.89 & 3.44 \\
\hline $\mathrm{CD}(\mathrm{p}=0.05)$ & NS & $\mathrm{NS}$ & NS \\
\hline CV $(\%)$ & 10.1 & 7.4 & 16.6 \\
\hline
\end{tabular}


Table.2 Economics of rice fallow mustard as influenced by seed rates and varieties

\begin{tabular}{|c|c|c|c|c|}
\hline Treatment & $\begin{array}{c}\text { Cost of cultivation } \\
\left(\operatorname{Rs~ha}^{-1}\right)\end{array}$ & $\begin{array}{l}\text { Gross Return } \\
\quad\left(\text { Rs ha }^{-1}\right)\end{array}$ & $\begin{array}{c}\text { Net } \\
\text { Return } \\
\left(\text { Rs ha }^{-1}\right)\end{array}$ & $\begin{array}{l}\text { Return per Rupee } \\
\text { Investment }\end{array}$ \\
\hline \multicolumn{5}{|c|}{ Seed rates $\left(\mathrm{kg} \mathrm{ha}^{-1}\right)$} \\
\hline$S_{1}-6$ & 11480 & 25445 & 13966 & 1.22 \\
\hline$S_{2}-8$ & 11640 & 25990 & 14350 & 1.23 \\
\hline$S_{3}-10$ & 11800 & 27036 & 15236 & 1.29 \\
\hline$S_{4-12}$ & 11960 & 29268 & 17308 & 1.45 \\
\hline S.Em \pm & - & 908.17 & 776.77 & 0.06 \\
\hline $\mathrm{CD}(\mathrm{p}=\mathbf{0 . 0 5})$ & - & 2663 & 2277 & 0.17 \\
\hline \multicolumn{5}{|l|}{ Varieties } \\
\hline NPJ-112 & 11720 & 27840 & 16120 & 1.37 \\
\hline PM-28 & 11720 & 29961 & 18241 & 1.56 \\
\hline Pusa bold & 11720 & 23005 & 11285 & 0.96 \\
\hline S.Em \pm & - & 786.50 & 672.70 & 0.05 \\
\hline $\mathrm{CD}(\mathrm{p}=\mathbf{0 . 0 5})$ & - & 2306 & 1972 & 0.15 \\
\hline \multicolumn{5}{|c|}{ Interaction (S X V) } \\
\hline S.Em \pm & - & 1573.00 & 1345.40 & 0.10 \\
\hline $\mathrm{CD}(\mathrm{p}=0.05)$ & - & NS & NS & NS \\
\hline CV (\%) & - & 10.1 & 15.3 & 13.8 \\
\hline
\end{tabular}

Significantly the highest gross return was recorded in the variety PM-28 (Rs29, 961 $\mathrm{ha}^{-1}$ ), which was on par with NPJ-112 (Rs 27, $\left.840 \mathrm{ha}^{-1}\right)$. Whereas the lowest gross returns (Rs 23, $005 \mathrm{ha}^{-1}$ ) was reported in the variety Pusa bold. Significantly the highest net return was recorded in the variety PM-28 (Rs 18, $241 \mathrm{ha}^{-1}$ ), which was on par with NPJ-112 (Rs16, $\left.120 \mathrm{ha}^{-1}\right)$. Whereas the lowest net returns (Rs11, $285 \mathrm{ha}^{-1}$ ) was reported in the variety Pusa bold.

Significantly the highest return per rupee invested was recorded in the variety PM-28 (Rs 1.56), which was on par with NPJ-112 (Rs 1.37). Whereas the lowest return per rupee invested (Rs 0.96) was reported in the variety Pusa bold. This might be ascribed to higher seed and stalk yield in the variety PM28. Results of the current experiment are in conformity with the findings of Meena et al (2017).
It can be concluded that $12 \mathrm{~kg} \mathrm{ha}^{-1}$ seed rate registered higher yield, gross return, net return and return per rupee invested and hence $12 \mathrm{~kg}$ seed rate $\mathrm{ha}^{-1}$ was found to be optimum in rice-fallows compared to $10 \mathrm{~kg} \mathrm{ha}^{-1}, 8 \mathrm{~kg}$ $\mathrm{ha}^{-1}$ and $6 \mathrm{~kg} \mathrm{ha}^{-1}$ seed rates. Among varieties PM-28 variety performed better than NPJ-112 and Pusa bold with higher yield, gross return, net return and return per rupee invested.

\section{References}

BebiGogoi, Thakuria, K.K.K., Ojha, N.J and Dutta, S. 2017. Influence of crop management practices on late sown toria (Brassica campestries var. toria) under rainfed rice-fallow situation of Assam. J. Oilseed Brassica, 81(2): 168-174.

http://www.indiastat.com, Ministry of Agricultural, Government of India, 2014-15. 
Khorshidi, M.G., Moradpoor, S., Ranji, A., Karimi, B and Khorie, M.M.A. 2014. Effect of different levels of nitrogen fertilizer and plant density on yield and yield components of canola. Scientific Journal of Crop Science, 3(10): 109-114.

Kumar, Y., Singh, R., Singh, D., Kumar, A and Dhaka, A.K. 2017. Influence of Weather Parameters on Yield and Yield Attributes of Mustard (Brassica juncea) at Hisar Condition. Environment Ecology, 35(2C): 1274-1280.

Ma, N., Yuan, J., Li, M., Li, J., Zhang, L., Liu, L., Naeem, M.S. and Zhang, C., 2014. Ideotype population exploration: growth, photosynthesis, and yield components at different planting densities in winter oilseed rape (Brassica napusL.). Plosone, 9(12): e114232.

Meena, D.S., Meena, V.R and Meena, A.K. 2013. Fertilizer management studies on growth and productivity of hybrid Indian mustard Brassica juncea(L.). Journal of Oilseed Brassica, 1(1): 39-42.
Meena, H., Meena, P.K.P and Kumhar, B.L. 2017. Studies on Response of Mustard Varieties to Different Sowing Dates under Humid Southern Plain Zone of Rajasthan, International Journal of Pure and Applied Bioscience 5(3): 385-391.

Neha, Dashora, L.N., Kaushik, M.K and Upadhyay, B. 2014. Yield, nutrient content, uptake and quality of Indian mustard genotypes as influenced by sulphur under Southern Rajasthan conditions. Annals of Agri Bio Research, 19(1): 81-84.

Sharma, P. 2013. Effect of varieties and fertility levels on yield and nutrient uptake of mustard in western region of Madhya Pradesh. TECHNOFAME- A Journal of Multidisciplinary Advance Research, 2(2): 67-69.

Thakuria, K and Thakuria, C. 2014. Seed rate and row spacing effect on yellow sarson (Brassica rapa var. trilocularis). Under rainfed conditions. Journal of Oilseeds Research. 31(1):77-78.

\section{How to cite this article:}

Rajyalakshmi, B., B. Venkateswarlu and Prasad, P.V.N. 2019. Effect of Seed Rates and Varieties on Yield of Rice Fallow Mustard and their Economics. Int.J.Curr.Microbiol.App.Sci. 8(02): 2551-2556. doi: https://doi.org/10.20546/ijcmas.2019.802.297 